\title{
Interaction of Anionic Azo Dye and TTAB - Cationic Surfactant
}

\author{
Sayed Mehdi Ghoreishi,* Mohsen Behpour and Mehdi Shabani-Nooshabadi \\ Department of Chemistry, Faculty of Science, University of Kashan, Kashan, I.R. Iran
}

\begin{abstract}
A interação entre três corantes aniônicos azo: C.I. Vermelho Ácido 14 (AR14), C.I. Vermelho Ácido 1 (AR1), C.I. Laranja Ácido 7 (AO7) e um surfactante catiônico, o brometo de tetradeciltrimetilamônio (TTAB), foi investigada por meio da técnica de eletrodo seletivo para surfactante. O eletrodo seletivo para TTAB foi construído e usado para determinar a concentração de monômeros TTAB e, também, de íons surfactantes ligados aos corantes por medidas de força eletromotriz. A constante de formação do complexo corante-surfactante, $K_{1}$, e a variação da energia livre de Gibbs, $\Delta \mathrm{G}_{1}{ }^{0}$, foram obtidas a partir dos dados experimentais. Os resultados indicaram que no sistema TTAB/AO7, no qual o corante AO7, mais hidrofóbico, é usado, as interações corante-surfactante são mais fortes do que em outros sistemas. Os resultados também indicaram que ambas interações, hidrofóbica e atração eletrostática, são muito importantes para a formação do complexo entre os corantes e o surfactante. A capacidade máxima de ligação dos corantes de cargas opostas e também o grau de ligação do surfactante aos corantes foram calculados a partir dos dados experimentais.
\end{abstract}

Interaction between three anionic azo dyes, C.I. Acid Red 14 (AR14), C.I. Acid Red 1 (AR1), C.I. Acid Orange 7 (AO7) and a cationic surfactant tetradecyltrimethylammonium bromide (TTAB) has been investigated using surfactant selective electrode technique. The TTAB selective electrode was constructed and used to determine the concentration of TTAB monomers and also surfactant ions bounded to dyes by electromotive force data. The dye-surfactant complex formation constant, $\mathrm{K}_{1}$, and the standard free energy change, $\Delta \mathrm{G}_{1}{ }^{0}$, could be obtained from the experimental data. The results indicate that in the TTAB/AO7 system, where the more hydrophobic dye AO7 is used, the dye-surfactant interactions are stronger than in other systems. The results also indicate that both the electrostatic attractive and the hydrophobic interactions are very important for the formation of the complex between the oppositely-charged dyes and the surfactant. Maximum binding capacities of the dyes and also the degree of binding of the surfactant to the dyes were calculated from the experimental data.

Keywords: ion selective electrode, anionic azo dye, dye-surfactant interactions, TTAB, Acid Red 14, Acid Red 1, Acid Orange 7

\section{Introduction}

The use of water as a medium for textile processing ideally requires that liquid wets the fiber surfaces quickly and uniformly, and here surfactants play a useful role. In addition, surfactants are required for detergency, achievement of level dyeing, and so on. The choice of a particular surfactant for a particular purpose depends on its ability for interaction to fibers and/or other components in the system. Surfactants contain both hydrophobic and hydrophilic moieties and are adsorbed at interfaces between phases, lowering their interfacial tension. ${ }^{1}$

*e-mail: s.m.ghoreishi@kashanu.ac.ir
Surfactants are extensively used in our daily life and also in various industrial processes such as textiles, pulp and paper, paints, oil, metallurgy etc. Textile effluents contain many chemical substances arising from desizing, dyeing, printing and finishing processes. Surfactants that are used as levelling, dispersing and wetting agents in the dyeing process, act mostly in two ways. They can form a complex with ionic dyes or they can be adsorbed with nonionic dyes onto the fiber. ${ }^{2}$ Although the interaction between dyes and surfactants has been studied in many papers, the studies in this area are still important and interesting for improving the dyeing process from theoretical, technological, ecological and economical points of view. The investigations into the behavior of different dyes in aqueous surfactant 
solutions can give useful information for understanding the thermodynamics and kinetics of the dyeing process and the finishing of textile materials. ${ }^{3}$

Various parameters, the charge and the alkyl chain length of the surfactants and the type and the position of the substituents in the aromatic ring of the dye molecules, can affect the interactions between surfactant and dye molecules. It was found that structure of dye and surfactant are important for their mutual interaction as well as dye-fiber and surfactant-fiber interaction. Literature survey indicates, beside the electrostatic interaction, the hydrophobic interaction is also very important for the binding between the oppositely charged dyes and surfactants. ${ }^{4}$

Various techniques such as spectrophotometry, ${ }^{5-8}$ membrane selective electrode,${ }^{9}$ polarography, ${ }^{10}$ potentiometry ${ }^{11}$ and conductometry ${ }^{12-14}$ have been applied for studying of dye-surfactant interactions. Considerable studies have confirmed that surfactants can affect the spectra of the solutions of many dyes, ${ }^{15-17}$ due to aggregation of the dye molecules or dye-surfactant ion pairs and charge transfer between dye and surfactant molecules. ${ }^{18}$ The spectral changes of a dye observed in the presence of varying amount of surfactants are consistent with sequential equilibrium involving surfactant monomers, micelles, dye aggregates, premicellar dye-surfactant complex and dye incorporated into the micelle. ${ }^{19,20}$

This paper presents a potentiometric study of the interactions between three anionic azo dyes, i.e., C.I. Acid Red 14 (AR14), C.I. Acid Red 1 (AR1) and C.I. Acid Orange 7 (AO7), and a cationic surfactant tetradecyltrimethylammonium bromide (TTAB) in submicellar concentration ranges. The study of such systems can give more information about the influence of hydrophobic and electrostatic effects on the formation of the dye-surfactant complex in aqueous solution at surfactant concentrations below critical micelle concentration (CMC). The surfactant selective electrode is sensitive to free surfactant ions (the monomer surfactants), therefore the experimental results allow the direct determination of the concentration of the monomer surfactants $\left(\mathrm{m}_{1}\right)$ as well as the concentration of surfactant ions bound in the dye-surfactant complex. The dye-surfactant constant, $\mathrm{K}_{1}$, and the standard free energy change, $\Delta \mathrm{G}_{1}{ }^{0}$, could be also obtained.

\section{Experimental}

\section{Materials}

The anionic azo dyes C.I. Acid Red 1 (AR1), C.I. Acid Red 14 (AR14), C.I. Acid Orange 7 (AO7) and the cationic surfactant tetradecyltrimethylammonium bromide

(TTAB), were purchased from Aldrich and used without further purification.

All solutions were prepared in doubly distilled water. Chemical structures of dyes and surfactant are shown in Figure 1.

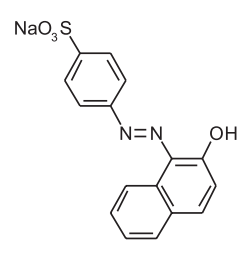

Acid Orange 7 (AO7)

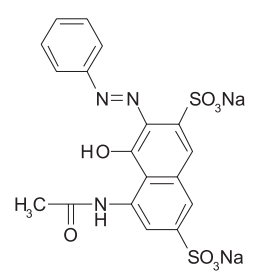

Acid Red 1 (AR1)

Figure 1. Structures of the dyes and surfactants.

\section{Potentiometric method}

The potentiometric titration was used as an experimental method. The use of the TTA-selective electrode, which was included the TTA cation-VC containing $\mathrm{SO}_{3} \mathrm{H}(0.1 \%)$ anion complex incorporated in an Elvaloy 742 gel membrane, ${ }^{21}$ enabled us to determine the concentration of free TTA surfactant cations in solution. Potentiometric measurements were carried out in the following electrode cell:

$\mathrm{Ag}|\mathrm{AgBr}|$ reference solution: $1 \times 10^{-5} \mathrm{~mol} \mathrm{~L}^{-1} \mathrm{TTAB}+$ $1 \times 10^{-4} \mathrm{~mol} \mathrm{~L}^{-1} \mathrm{NaBr} \mid$ polymer membrane | test solution | reference electrode (SCE)

The relationship between the EMF (E) of the cell and the TTAB total concentration $\left(\mathrm{C}_{1}\right)$ was measured in the concentration range $1 \times 10^{-5}$ to $1 \times 10^{-2}$ mol L-1 at $25^{\circ} \mathrm{C}$. The calibration curves represent plots of $\mathrm{E}$ versus $\mathrm{C}_{1}$ of TTAB without the addition of the dyes. The binding curves were obtained when measurements of $E$ versus $\mathrm{C}_{1}$ of TTAB were carried out in the presence of constant concentration of the dyes $\left(1 \times 10^{-3}, 5 \times 10^{-4}\right.$ and $\left.1 \times 10^{-4} \mathrm{~mol} \mathrm{~L}^{-1}\right)$. All solutions contained $1 \times 10^{-4} \mathrm{~mol} \mathrm{~L}^{-1} \mathrm{NaBr}$. The temperature used was $25^{\circ} \mathrm{C}$.

\section{Results and Discussion}

Interactions between the dyes and the surfactant were studied for the systems, TTAB/AR14, TTAB/AR1 and TTAB/AO7. 
Figure 2 shows plots of measured $\mathrm{E}_{\text {versus }} \mathrm{C}_{1}$ in aqueous solution when the different concentrations of the dye, AR14, $\left(\mathrm{C}_{\mathrm{d}}\right)$ are added to the solution. It is manifested from the figure that the calibration curve is linear over the concentration range from $1 \times 10^{-5}$ to $5 \times 10^{-3} \mathrm{~mol} \mathrm{~L}^{-1} \mathrm{TTAB}$ with a good slope, which indicates excellent agreement with the Nernstian response. In the presence of the dye, AR14, in the test solution, deviation from the linear response is considerable over the whole measured concentration range. This fact indicated that the formation of the dye-surfactant complex takes place.

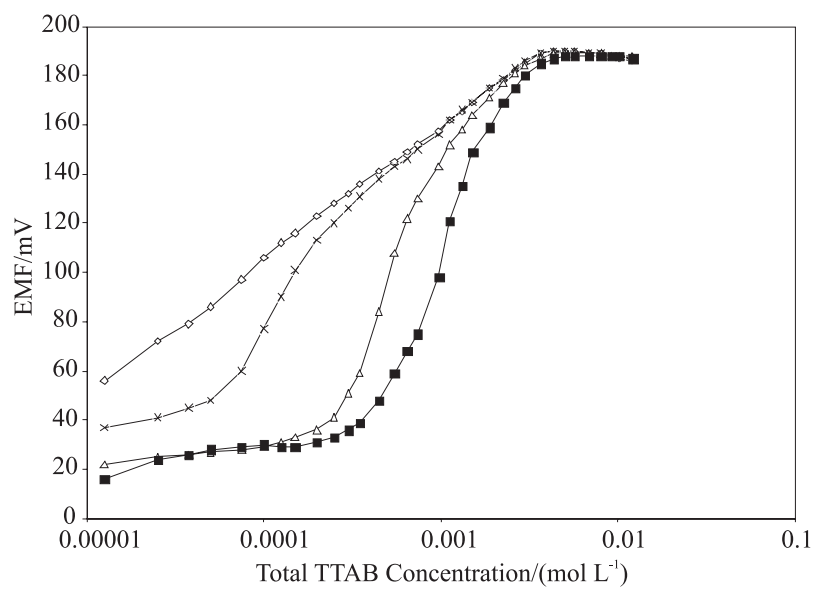

Figure 2. Plot of the EMF of the TTAB electrode as a function of the total TTAB concentration for the TTAB/AR14 system in the presence of different concentrations of dye: $(\diamond) 0 \mathrm{~mol} \mathrm{~L}^{-1}$ (calibration curve); $1 \times 10^{-3} \mathrm{~mol} \mathrm{~L}^{-1} ;(\triangle) 5 \times 10^{-4} \mathrm{~mol} \mathrm{~L}^{-1} ;(\times) 1 \times 10^{-4} \mathrm{~mol} \mathrm{~L}^{-1}$.

These curves also indicate that binding occurs even at very low TTAB concentrations and that the process continues until the dye display no interaction with the monomer of surfactant. This point is reached when the EMF values for the solutions with and without dyes merge in the micellar range. This is a result that Wyn-Jones and co-workers ${ }^{22}$ have obtained previously in connection with the binding of sodium dodecylsulfate (SDS) to the dendrimers and the cyclodextrins. When the EMF of the TTAB electrode merge, it shows that the dye is no longer involved in any further binding with TTAB or alternatively the dye can not interact with bound TTAB. The TTAB concentration corresponding to the merger is denoted $\mathrm{T}_{2}$.

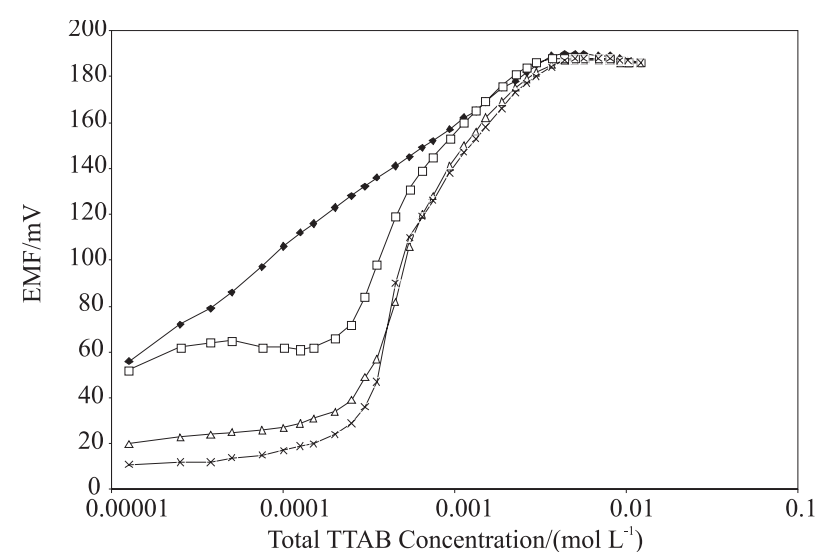

Figure 3. Plot of the EMF of the TTAB electrode as a function of the total TTAB concentration for TTAB/dye $\left(5 \times 10^{-4} \mathrm{~mol} \mathrm{~L}^{-1}\right)$ systems in $1 \times 10^{-4}$ mol L ${ }^{-1} \mathrm{NaBr}:(\bullet)$ pure TTAB; $(\triangle)$ TTAB + AR14; $(\square)$ TTAB + $\mathrm{AR} 1 ;(\times) \mathrm{TTAB}+\mathrm{AO} 7$.

The same results obtained for TTAB/AR1 and TTAB/ AO7 systems. Figure 3 for example shows plots of EMF versus $\mathrm{C}_{1}$ for $\mathrm{TTAB} / \mathrm{dye}\left(5 \times 10^{-4} \mathrm{~mol} \mathrm{~L}^{-1}\right)$ systems in $1 \times 10^{-4} \mathrm{~mol} \mathrm{~L}^{-1} \mathrm{NaBr}$.

Maximum binding capacity of the dyes is also obtained from the data. The values of $T_{2}-m_{1}$, where $m_{1}$ is the concentration of the TTAB monomers at $\mathrm{T}_{2}$, are listed in Table 1.

These values represent the maximum amount of TTAB that can bind to one dye molecule. At TTAB concentrations approaching the end of binding $\left(\mathrm{T}_{2}\right)$ the complex involve one dye containing 0.2-3.8 bound monomers of TTAB depending on the size and type of dyes.

At any $C_{1}$ (the total concentration of surfactant), the concentration of free surfactant, $\mathrm{m}_{1}$, was determined from the calibration curve at the same EMF value. A typical $\mathrm{m}_{1}$ versus $\mathrm{C}_{1}$ plot is shown in Figure 4 for TTAB/dye $\left(1 \times 10^{-3} \mathrm{~mol} \mathrm{~L}^{-1}\right)$ systems. Figure 4 clearly shows that in the presence of the dye the concentration of free surfactant, $\mathrm{m}_{1}$, is negligible (nearly zero) at low surfactant concentration and so, these results confirm that the formation of the dye-surfactant complex takes place even at very low surfactant concentration. A slight increase in $m_{1}$ with increasing $C_{1}$ is exactly the behavior expected when surfactant exclusively bind to the dye and a sudden increase in $m_{1}$ with increasing $C_{1}$ shows that

Table 1. Binding parameters for the TTAB/dye $\left(5 \times 10^{-4} \mathrm{~mol} \mathrm{~L}^{-1}\right)$ systems in $1 \times 10^{-4} \mathrm{~mol} \mathrm{~L}^{-1} \mathrm{NaBr}$

\begin{tabular}{lcccc}
\hline Dye & $\mathrm{T}_{2} /\left(\mathrm{mmol} \mathrm{L}^{-1}\right)$ & $\mathrm{m}_{1}$ at $\mathrm{T}_{2} /\left(\mathrm{mmol} \mathrm{L}^{-1}\right)$ & $\mathrm{T}_{2}-\mathrm{m}_{1} /\left(\mathrm{mmol} \mathrm{L}^{-1}\right)$ & {$[\mathrm{TTAB}] /[\mathrm{Dye}]$ at $\mathrm{T}_{2} /\left(\mathrm{mmol} \mathrm{L}{ }^{-1}\right)$} \\
\hline AO7 & 4.34 & 2.46 & 1.88 & 3.76 \\
AR14 & 2.61 & 2.01 & 0.6 & 1.2 \\
AR1 & 1.31 & 1.21 & 0.1 & 0.2 \\
\hline
\end{tabular}


there is no interaction between the dye and the monomer of surfactant. When $\mathrm{m}_{1}$ decreases or remains almost constant with increasing $\mathrm{C}_{1}$, it represents the formation of free micelles in solution.

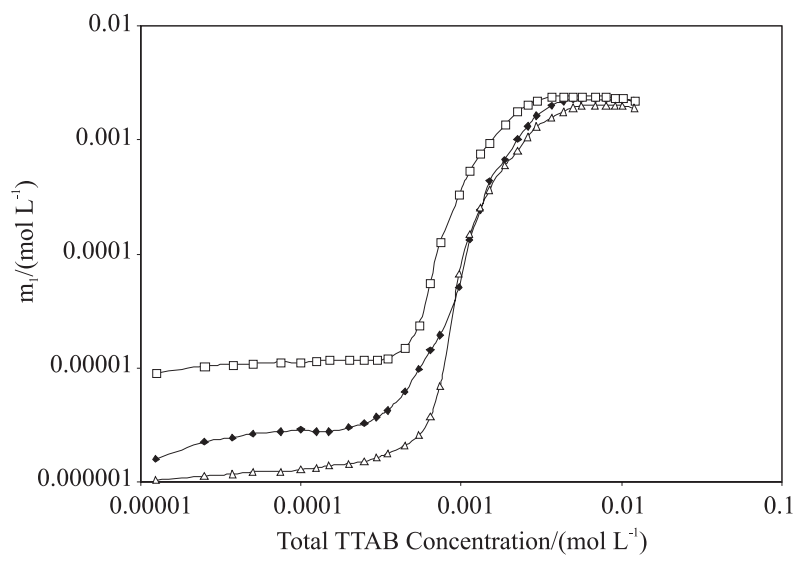

Figure 4. Plot of the TTAB monomer concentration $\left(m_{1}\right)$ as a function of the total TTAB concentration $\left(\mathrm{C}_{1}\right)$ for TTAB/dye $\left(1 \times 10^{-3} \mathrm{~mol} \mathrm{~L}^{-1}\right)$ systems in $1 \times 10^{-4} \mathrm{~mol} \mathrm{~L}^{-1} \mathrm{NaBr}:(\diamond)$ TTAB + AR14; ( $\square$ ) TTAB + AR1; $(\triangle)$ TTAB + AO7.

The experimental data also permit the calculation of the degree of binding of surfactant to dyes, $\beta$, defined as the concentration of bound surfactant divided by the dye concentration $\left(\beta=\frac{C_{1}-m_{1}}{C_{d}}\right.$ ) (commonly known as a binding ratio). Figure 5 shows the binding isotherms of TTAB/dye $\left(1 \times 10^{-3} \mathrm{~mol} \mathrm{~L}^{-1}\right)$ systems, where $\beta$ is plotted versus $\mathrm{m}_{1}$.

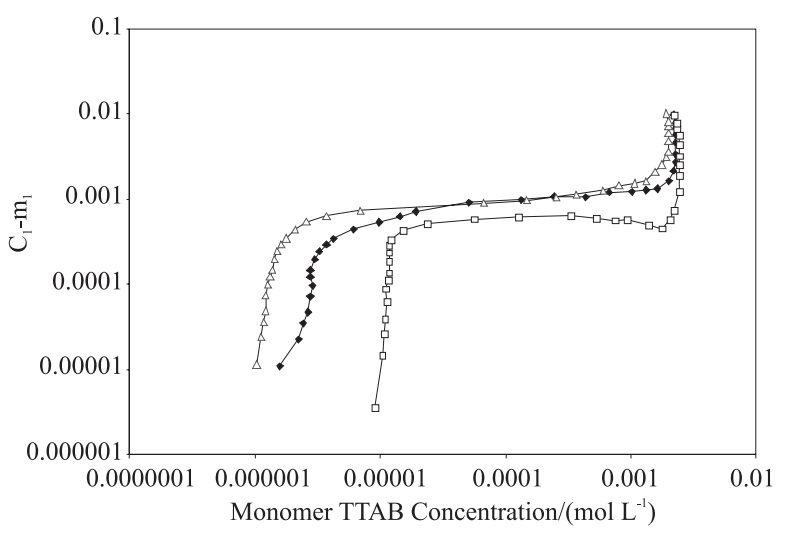

Figure 5. Binding isotherm in the form of a plot of $\mathrm{C}_{1}-\mathrm{m}_{1}$, as a function of monomer TTAB concentration for TTAB/dye $\left(1 \times 10^{-3} \mathrm{~mol} \mathrm{~L}^{-1}\right)$ systems in $1 \times 10^{-4} \mathrm{~mol} \mathrm{~L}^{-1} \mathrm{NaBr}:(\bullet) \mathrm{TTAB}+\mathrm{AR} 14 ;(\square) \mathrm{TTAB}+\mathrm{AR} 1 ;(\triangle) \mathrm{TTAB}+$ AO7.

It can be seen from Figure 5 that the degree of TTA cation binding to AO7 anions is much higher than of TTA cations to AR14 and AR1 anions. The binding ratio of TTAB/dye systems is small at low surfactant concentrations.
The dye-surfactant complex formation constant, $\mathrm{K}_{1}$, is calculated according to the method proposed by Simoncic and $\mathrm{Kert}^{23}$ were applied.

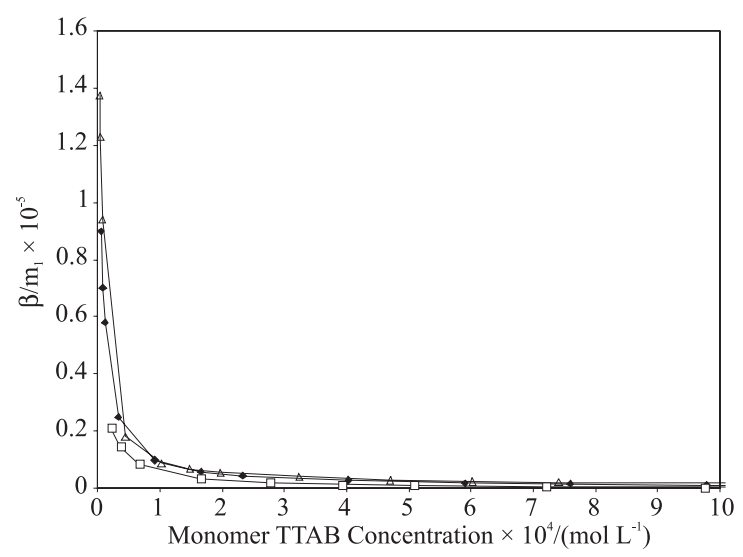

Figure 6. Plots of values of $\beta / m_{1}$ versus $m_{1}$ obtained for TTAB/dye $\left(5 \times 10^{-4} \mathrm{~mol} \mathrm{~L}^{-1}\right)$ systems in $1 \times 10^{-4} \mathrm{~mol} \mathrm{~L}^{-1} \mathrm{NaBr}:(\bullet) \mathrm{TTAB}+\mathrm{AR} 14$; $(\square) \mathrm{TTAB}+\mathrm{AR} 1 ;(\triangle) \mathrm{TTAB}+\mathrm{AO}$.

If the values of $\beta / m_{1}$ are plotted against $m_{1}$, the value $K_{1}$ is obtained by the extrapolation to zero free TTAB concentration. In Figure 6 the determination of complex formation constants for some typical studied systems are shown. The values of $\mathrm{K}_{1}$ for TTAB/dye systems are collected in Table 2 .

Furthermore, from the values of $\mathrm{K}_{1}$, the standard free energy change for complex formation is calculated, as follows: ${ }^{24}$

$\Delta \mathrm{G}_{1}^{0}=-\mathrm{RT} \ln \mathrm{K}_{1}$

These results are also reported in Table 2. It is evident that the value of $\mathrm{K}_{1}$ slightly increases by increasing the dye concentration.

The results show that the strength of dye-surfactant interaction and the stability of complex formed increase with the increasing in $\mathrm{K}_{1}$ value and consequently with the decrease in $\Delta \mathrm{G}_{1}{ }^{0}$ value. Strength of interaction also increases with the increase in hydrophobicity of the dye.

Similar results were reported by Tunc and Duman ${ }^{25}$ and Akbas and Kartal. ${ }^{26}$ They studied the interaction between anionic dyes and cationic surfactants using a conductometric technique. The calculated $\mathrm{K}_{1}$ and $\Delta \mathrm{G}_{1}{ }^{0}$ values in the present paper are comparable with their results.

The lowest of the $\Delta \mathrm{G}_{1}{ }^{0}$ values and also the largest of the $\mathrm{K}_{1}$ values for TTAB/dye systems are in the case of interactions between TTAB and $\mathrm{AO} 7$ whose hydrophobic groups are larger than those of AR14 and AR1. These data indicate that in the TTAB/AO7 system, the dye-surfactant interaction is stronger than that in the TTAB/AR14 and TTAB/AR1 systems. 
Table 2. Complex formation constant $\left(\mathrm{K}_{1}\right)$, the standard free energy change $\left(\Delta \mathrm{G}_{1}{ }^{0}\right)$ and the precipitation range of TTAB/dye systems (N means no dissolution was observed)

\begin{tabular}{lcccc}
\hline Dye & Dye Conc. / $\left(\mathrm{mol} \mathrm{L}^{-1}\right)$ & $\mathrm{K}_{1} \times 10^{-5} /\left(\mathrm{L} \mathrm{mol}^{-1}\right)$ & $\Delta \mathrm{G}_{1}{ }^{0} /\left(\mathrm{kJ} \mathrm{mol}^{-1}\right)$ & Precipitation range $/\left(\mathrm{mmol} \mathrm{L}^{-1}\right)$ \\
\hline AO7 & 0.001 & 2.5 & -30.8 & $0.33-2.96$ \\
& 0.0005 & 1.75 & -29.9 & $0.25-2.61$ \\
& 0.0001 & 0.6 & -27.3 & $0.05-0.45$ \\
AR14 & 0.001 & 1.3 & -29.2 & $0.64-1.12$ \\
& 0.0005 & 1.1 & -28.8 & $0.45-0.54$ \\
& 0.0001 & 0.6 & -27.3 & $c l e a r$ \\
AR1 & 0.001 & 0.4 & -26.3 & $0.05-\mathrm{N}$ \\
& 0.0005 & 0.3 & -25.5 & $0.05-\mathrm{N}$ \\
& 0.0001 & 0.125 & -23.4 & $0.05-\mathrm{N}$ \\
\hline
\end{tabular}

The values of $\Delta \mathrm{G}_{1}{ }^{0}$, which is an indication of the tendency for the formation of the dye-surfactant complex, show that TTAB interacts with AO7 is more favorably and stronger than AR14 and at the same conditions. The results are also confirmed by data from Figures 2-5.

In the studied systems (TTAB/dyes) in addition to complex formation between dye and surfactant, precipitate formation was also observed. The precipitation of dye with surfactant at special concentration of surfactant takes place and the precipitation range are also collected in Table 2.

According to these data, the necessary concentration ranges for the precipitation and dissolution are different in TTAB/dye systems. In the TTAB/AO7 system the beginning of the precipitation depends on the dye concentration and with any increase in the dye concentration the precipitation takes place at higher surfactant concentrations. The dissolution of formed precipitate occurs at higher surfactant concentration at comparison to the beginning place of the precipitation (and below the CMC, $<4 \times 10^{-3} \mathrm{~mol} \mathrm{~L}^{-1}$ ).

Therefore whenever the dye concentration is small, the necessary surfactant concentration range for the precipitation and dissolution is lower. Namely, when the dye concentration increases, the precipitation and dissolution take place at larger surfactant concentration range.

The TTAB/AR14 system is different from the TTAB/ AO7 system in some cases. First, the precipitation occurs at higher surfactant concentration. Secondly, the necessary surfactant concentration range for the formation and stability of precipitate is much lower and the precipitate after formed dissolves with addition of small amount of surfactant. The precipitation and dissolution have not been observed at $1 \times 10^{-4} \mathrm{~mol} \mathrm{~L}^{-1}$ of dye.

The TTAB/AR1 system differs from the two previous systems. The precipitation takes place at very low surfactant concentrations and the dissolution of precipitate has not been observed even at surfactant concentrations higher than CMC.

\section{Conclusions}

Potentiometric measurements using surfactant selective electrode was used to investigate the interaction between three anionic azo dyes and a cationic surfactant. With this method the dye-surfactant complex formation constant can be directly determined from the electromotive force measurements.

It was found that TTAB binds to all of the three dyes, AO7, AR14 and AR1, at surfactant concentrations lower than $1 \times 10^{-5} \mathrm{~mol} \mathrm{~L}^{-1}$. Our results also show that the interaction between $\mathrm{AO} 7$ and TTAB is stronger than that between other dyes and TTAB accompanied with the highest value of $\mathrm{K}_{1}$ and the lowest value of $\Delta \mathrm{G}_{1}{ }^{0}$.

The results also indicate that both the electrostatic attraction and the hydrophobic interactions are very important for the formation of the complex between the oppositely-charged dyes and surfactants.

\section{Acknowledgment}

The authors gratefully acknowledge financial support from Kashan University.

\section{References}

1. Datyner, A.; Surfactant Science Series, Marcel Dekker: New York, 1983, vol. 2.

2. Majewska-Nowak, K.; Kowalska, I.; Kabsch-Korbutowicz, M.; Desalination 2006, 198, 149.

3. Tehrani Bagha, A. R.; Bahrami, H.; Movassagh, B.; Arami, M.; Menger, F. M.; Dyes Pigm. 2007, 72, 331.

4. Simoncic, B.; Span, J.; Dyes Pigm. 1998, 36, 1. 
5. Malyukin, Yu, V.; Efimova, S. L.; Kemnitz, K.; J. Lumin. 2001, 94, 239.

6. Kartal, C.; Akbas, H.; Dyes Pigm. 2005, 65, 191.

7. Huang, X.; Yang, J.; Zhang, W.; Zhang, Z.; Zesheng, A.; J. Chem. Educ. 1999, 76, 93.

8. Chiril, E.; Carazeanu, I.; Dobrina, S.; Talanta 2000, 53, 271.

9. Ghoreishi, S. M.; Shabani, M.; Dyes Pigm. 2005, 65, 117.

10. Navarro, A.; Sanz, F. J.; J. Colloid Interface Sci. 2001, 237, 1.

11. Simoncic, B.; Kert, M.; Dyes Pigm. 2002, 54, 221.

12. Jocic, D.; Text. Res. J. 1995, 65, 409.

13. Mata, J.; Varade, D.; Bahadur, P.; Thermochim. Acta 2005, 428, 147.

14. Nasiruddin Khan, M.; Sarwar, A.; Fluid Phase Equilib. 2006, 239, 166.

15. Colichman, E.; J. Am. Chem. Soc. 1951, 73, 3385.

16. Rosendorfova, J.; Cermakova, L.; Talanta 1980, 27, 705.

17. Khamisa, M.; Bulosb, B.; Jumeanc, F.; Manassraa, A.; Dakiky, M.; Dyes Pigm. 2005, 66, 179.
18. Rohatgi-Mukherjee, K. K.; Chaudhuri, R.; Bhowmik, B. B.; J. Colloid Interface Sci. 1985, 106, 45.

19. Shah, S. S.; Laghari, G. M.; Naeem, K.; Thin Solid Films 1999, 346, 145.

20. Sarkar, M.; Poddar, S.; J. Colloid Interface Sci. 2000, 221, 181.

21. Davidson, C. J.; Ph.D. Thesis, Aberdeen University, Aberdeen, UK, 1998.

22. Ghoreishi, S. M.; Li, Y.; Bloor, D. M.; Warr, J.; Wyn-Jones, E.; Langmuir 1999, 15, 4380.

23. Simocic, B.; Kert, M.; Dyes Pigm. 2008, 76, 104.

24. Moore, W.J.; Physical Chemistry, Longman Scientific and Technical: London, 1972.

25. Tunc, S.; Duman, O.; Fluid Phase Equilib. 2007, 251, 1.

26. Akbas, H.; Kartal, C.; Dyes Pigm. 2007, 72, 383.

Received: August 5, 2008 Web Release Date: February 13, 2009 